\title{
hypertensive medicinal treatment for african descent people resident in quilombola community: a cross-sectional study
}

\author{
Factores asociados con la adherencia al tratamiento farmacológico de \\ afrodescendientes hipertensos residentes en la comunidad de quilombola: un \\ estudio transversal \\ Fatores associados à adesão ao tratamento medicamentoso de \\ afrodescendentes hipertensos residentes em comunidade quilombola: um \\ estudo transversal
}

How to cite this article:

Rosa, Randson Souza; Silva, Jaine Kareny; Ribeiro, Ícaro José dos Santos; Mussi, Ricardo Franklin de Freitas; Damasceno, Rudson Oliveira; Santos, Isleide Santana Cardoso; Fonseca, Jorge Lucas Teixeira; Boery, Rita Narriman Silva de Oliveira. Factors associated to adherence to hypertensive medicinal treatment for african descent people resident in Quilombola community: a cross-sectional study. Revista Cuidarte. 2020;11(3):e1168. http://dx.doi.org/10.15649/cuidarte.1168

\section{Revista Cuidarte Rev Cuid. 2020; 11(3): e1168}

doij $h$ ttp://dx.doi.org/10.15649/cuidarte.1168 E-ISSN: 2346-3414

(1) Randson Souza Rosa

(1) Jaine Kareny da Silva²

(1) Ícaro José dos Santos Ribeiro ${ }^{3}$

(1) Ricardo Franklin de Freitas Mussi ${ }^{4}$

(1) Rudson Oliveira Damasceno 5

(1) Isleide Santana Cardoso Santos ${ }^{6}$

(1) Jorge Lucas Teixeira da Fonseca ${ }^{7}$

(1) Rita Narriman Silva de Oliveira Boery $^{8}$

1 MSc Nursing and Health, Health Department, Postgraduate Program in Nursing \& Health, State University of Southwest Bahia (UESB) Jequie, BA, Brazil. E-mail enfrandson@gmail. com Autor for correspondence.

2 PhD. Professor, Department of Education, State University of Bahia (UNEB), Guanambi, BA, Brazil.

E-mail: jainekareny@yahoo.com.br

3 PhD Nursing and Health, Health Department, Postgraduate Program in Nursing \& Health, State University of Southwest Bahia (UESB), Jequie, BA, Brazil.

E-mail: icaro.ribeiro29@gmail.com

$4 \mathrm{PhD}$. Professor, Department of Education, State University of Bahia (UNEB), Caetité, BA, Brazil.E-mail: rimussi@yahoo.com.br

5 MSc Nursing and Health, Health Department, Postgraduate Program in Nursing \& Health, State University of Southwest Bahia (UESB), Jequie, BA, Brazil.

E-mail: rudsondamasceno@gmail.com

6 PhD Student Nursing and Health, Health Department, Postgraduate Program in Nursing \& Health, State University of Southwest Bahia (UESB), Jequie, BA, Brazil. E-mail: isleide71@yahoo.com.br

7 PhD Student in Pharmacology, Postgraduate Program in Pharmacology, Federal University of São Paulo, Sao Paulo, SP, Brazil. E-mail: jlukas23@hotmail.com

8 PhD. Professor, Health Department, Professor of the postgraduate program in nursing health, State University of Southwest Bahia (UESB), Jequie, BA, Brazil. E-mail: rboery@uesb.edu.br

\section{Abstract}

Introduction: Hypertension is a severe public health problem, especially in African descent people, such as those living in quilombos. Drug adherence helps reducing blood pressure levels. However, little is known about the factors related to drug adherence in hypertensive people living in the urban quilombola community. Objetive: To analyze the adherence to drug treatment and factors associated with cardiovascular health in Afro-descendants with hypertension, living in families from the urban quilombola community. Material and Methods: A cross-sectional delineate, community-based census study carried out in an urban quilombola community in a municipality of the Brazilian northeast. The study population consisted of 302 people between 35 and 79 years old, of both genders and with a diagnosis of arterial hypertension registered in medical records of the adscript basic health unit. The following instruments were used for data collect: a questionnaire on arterial hypertension in primary care and Morisky's drug adherence scale (MMAS-8). Results: There was a predominance of black hypertensive female subjects, low schooling and financial income, resident with relatives, retirees and not working. In the analysis of multiple regression the following was associated with drug adherence: Female Gender (OR 0.50 95\% IC: 0.29-0.89, Adjusted OR 0.49 95\% Cl: 0.29-0.84), age (OR 0,96 95\% IC: 0.96-0.99 Adjusted OR 0.95 95\% Cl: 0.93-0.97) and systolic blood pressure (SBP) (OR 1,00 95\% IC: 0.99-1.02, Adjusted OR 1.11 95\% Cl:1.00-1.02). Of the hypertensive people who adhered to the medication, $91 \%$ lived with a companion and the majority had a sedentary behavior. Conclusions: The variables gender, age and SBP influence drug adherence of hypertensive people living in the urban quilombola community. Living with relatives can positively influence this adherence. Promoting interventions that encourage the adoption of healthy life habits can potentiate blood pressure control.

Key words: Treatment Adherence and Compliance; Hypertension; Minority Groups; African Continental Ancestry Group.
Receibed: march 25th, 2020

Accepted: may 22th, 2020

Published: september 1st, 2020 $\square *$ Correspondence Randson Souza Rosa E-mail: enfrandson@gmail.com 


\section{Factores asociados con la adherencia al tratamiento farmacológico de afrodescendientes hipertensos residentes en la comunidad de quilombola: un estudio transversal}

\section{Resumen}

Introducción: la hipertensión es un grave problema de salud pública, especialmente en personas de ascendencia africana, como las que viven en quilombos. La adherencia a los medicamentos ayuda a reducir los niveles de presión arterial. Sin embargo, se sabe poco sobre los factores relacionados con la adherencia a las drogas en personas hipertensas que viven en la comunidad urbana de quilombola. Objetivo: analizar la adherencia al tratamiento farmacológico y los factores asociados con la salud cardiovascular, en personas con hipertensión arterial, que viven en comunidades urbanas de quilombolas. Materiales y Métodos: Estudio censal, transversal y comunitario, realizado en una comunidad urbana de quilombolas en un municipio del noreste de Brasil. La población de estudio fue de 302 personas de 35 a 79 años, de ambos sexos y diagnosticadas con hipertensión arterial registrada en el registro médico de la unidad básica de salud ingresada. Para la recolección de datos, se utilizaron los siguientes instrumentos: cuestionario de hipertensión arterial en atención primaria y la escala de adherencia a la medicación de Morisky (MMAS-8). Resultados: Había un predominio de sujetos femeninos hipertensos negros, baja escolaridad e ingresos financieros, residentes con familiares, jubilados y que no trabajaban. En el análisis de regresión múltiple, lo siguiente se asoció con la adherencia al fármaco: sexo femenino (OR 0.50 IC 95\%: 0.29-0.89, OR ajustado 0.49 IC 95\%: 0.29-0.84), edad (OR 0,96 IC 95\%: 0.96 -0.99 OR ajustado 0.95 95\% IC: 0.93-0.97) y presión arterial sistólica (PAS) (OR 1,00 95\% IC: 0.99-1.02, OR ajustado 1.11 95\% IC: 1.00-1.02). De las personas hipertensas que se adhirieron a la medicación, el $91 \%$ vivía con un compañero y la mayoría tenía un comportamiento sedentario. Conclusiones: Las variables, sexo, edad y PAS influyen en la adherencia a la medicación de las personas hipertensas que viven en una comunidad urbana de quilombolas. Vivir con miembros de la familia puede influir positivamente en esta adhesión. Promover intervenciones que fomenten la adopción de hábitos de vida saludables puede mejorar el control de la presión arterial.

Palabras clave: Cumplimiento y Adherencia al Tratamiento; Hipertensión; Grupos Minoritarios; Grupo de Ascendencia Continental Africana.

\section{Fatores associados à adesão ao tratamento medicamentoso de afrodescendentes hipertensos residentes em comunidade quilombola: um estudo transversal}

\section{Resumo}

Introdução: A hipertensão é um grave problema de saúde pública, principalmente em pessoas de ascendência africana, como as que vivem em quilombos. A adesão ao medicamento ajuda a reduzir os níveis de pressão arterial. Entretanto, pouco se sabe sobre os fatores relacionados à adesão às drogas em hipertensos residentes na comunidade urbana quilombola. Objetivo: Analisar a adesão ao tratamento medicamentoso e fatores associados à saúde cardiovascular, em afrodescendentes hipertensos, residentes em famílias de comunidade quilombola urbana. Materiales e Métodos: Estudo censitário, de delineamento transversal e base comunitária, realizado em uma comunidade quilombola urbana em um município do nordeste brasileiro. A população do estudo foi de 302 pessoas com idade entre 35 à 79 anos, de ambos os sexos e com diagnóstico de hipertensão arterial registrado em prontuário da unidade básica de saúde adscrita. Para a coleta de dados utilizou-se os instrumentos: questionário de hipertensão arterial na atenção primária e escala de adesão medicamentosa de Morisky (MMAS-8). Resultados: Houve predomínio de mulheres negras hipertensas, baixa escolaridade e renda financeira, residentes com parentes, aposentados e não trabalhar. Na análise de regressão múltipla, associou-se a adesão à droga: Sexo Feminino (OR 0,50 IC 95\%: 0,29-0,89, OR ajustado 0,49 IC 95\%: 0,29-0,84), idade (OR 0,96 IC 95\%: 0,96 -0,99 OR ajustado 0,95 IC95\%: 0,93-0,97) e pressão arterial sistólica (PAS) (OR 1,00 IC95\%: 0,99-1,02, OR ajustado 1,11 IC95\%: 1,00-1,02). Das hipertensas que aderiram ao medicamento, 91\% moravam com companheiro e a maioria apresentava comportamento sedentário. Conclusões: As variáveis, sexo, idade e PAS influenciam na adesão medicamentosa de pessoas hipertensas residentes em comunidade quilombola urbana. Conviver com familiares pode influenciar positivamente nesta adesão. Promover intervenções que incentivem a adoção de hábitos saudáveis de vida podem potencializar o controle da pressão arterial.

Palavras chave: Cooperação e Adesão ao Tratamento; Hipertensão; Grupos Minoritários; Grupo de Ancestrais do Continente Africano. 


\section{Introduction}

Arterial Hypertension (AH) is considered a serious health problem worldwide as it is the main modifiable risk factor for circulatory system diseases ${ }^{1}$ and, due to their high prevalence, especially in low and middle-income countries ${ }^{2}$. Among these, Brazil experienced an increase in annual death rates reaching $21.4 \%$ of its population ${ }^{3}$. Due to this morbidity and mortality, adherence to appropriate treatment, which is the primary mode for controlling the $\mathrm{AH}$, is still a major challenge ${ }^{1,4}$.

In 2003, the World Health Organization defined adherence Therefore, adherence involves as a person's commitment to maintaining medication and drug treatments or not. diet or changes in lifestyle habits, according to recommendations of a health professional ${ }^{5}$. Therefore, adherence involves drug treatments or not.

Regarding drug adherence in people with $\mathrm{AH}$, this is a complex and multifactorial process that may be influenced by factors related to lack of blood pressure control ${ }^{6}$, to the socio-demographic profile, to the disease, to the patient, to the health professional, to the relationship between the health professional and the patient, to the treatment, to the health service, to the use of substances, to social problems ${ }^{7}$ and cultural aspects ${ }^{8}$.

In this regard, researchers have emphasized the need for further studies on antihypertensive drug adherence that takes into account, among other factors, the culture ${ }^{8}$ and the race ${ }^{9}$. Thus, the development of these studies in the black population is urgent, since it is more affected by $\mathrm{AH}$ in relation to the other races ${ }^{10}$.

In the national territory, the black ancestry population, which includes people who declared themselves black and mulattos ${ }^{11}$, has a high AH prevalence ${ }^{12}$. Among this population, the most prominent are the people living in quilombola communities that show, in addition to their own ethnic-racial identity ${ }^{13}$, a significant level of social vulnerability ${ }^{14}$, poor housing conditions $\mathrm{s}^{15}$ and difficulties in accessing health services ${ }^{16}$, which may compromise adherence to antihypertensive treatment.

In general, quilombola communities are located in rural areas and the few studies that involve the identification of their health conditions are concentrated in these localities ${ }^{14,17}$. Therefore, studies aimed at investigating drug adherence and its associated factors in hypertensive quilombola people ${ }^{12}$, are incipient, especially in the urban quilombola community.

The identification of drug adherence and associated factors is relevant, and its analysis in different regional contexts ${ }^{18}$ can provide subsidies for health professionals, researchers and managers in formulating public policies to reverse this health problem $(\mathrm{AH})$ and in creating interventions that may come to promote the health of these people and increase the adherence rates ${ }^{4}$.

Therefore, the study's objective is to identify adherence to drug treatment and the associated factors, socio-demographic and health aspects, in hypertensive individuals, living in urban quilombola community.

\section{Materials and methods}

This is a analytical cross-sectional, community-based census study conducted in the community of Barro Preto, located in the urban area of Jequié-BA (Brazilian northeast), within the Family 
Health Strategy (FHS) scope area, where black and hypertensive people reside, and who are remaining quilombola people.

Data collect occurred between November 2017 and March 2018. Inclusion criteria were as it follows: being between 35 and 79 years old; self-declared as a quilombola resident, mulatto or black people; residing in the studied community; being enrolled in the FHS in their territory and have the medical $\mathrm{AH}$ diagnosis recorded in a medical record. People who were not located after three home visits at distinct days and times were excluded, those with incomplete questionnaire data, and that moved away from the community were also excluded.

In the FHS records there were 483 people registered in HiperDia. In order to carry out the survey on the people enrolled in the FHS of the studied quilombola community, a search was accomplished on Sheet A of the family history record, with 400 hypertensive people being foun that met the eligibility criteria. However, through home visits, 89 people were not found, 4 moved away and 5 had incomplete questionnaires, resulting in 302 people.

The interview technique was used for applying the instruments, starting with the AH form, that is routinely used in this FHS and containing the independent variables related to socio-demographic data (age, gender, marital/family status, schooling, race/color, occupation and family income) and health aspects (comorbidity, lifestyle and anthropometric index) evaluated in this study. The pilot test was not accomplished, since it is a standard form in the health service where the study was accomplished.

Then, to evaluate drug adherence, a variable dependent on this study, the participants responded to the Morisky Drug Adherence Scale (MMAS-8), validated ${ }^{19,20}$ and used in other Brazilian studies ${ }^{7}$. The questionnaire contains eight questions and the possible answers are "yes" and "no". For each "no" answer, 1 point is added. At the end of the summation, the adherence classification is obtained in three levels: high (score 8), mean (score 6 and 7) and low (score <6) values. In this study, those participants with scores equal to or greater than 6 in the MMAS- 8 and non-adherent ones whose final score was less than $6^{19}$.

Data arising from the collect were tabulated in the software Statistical Package for the Social Sciences (SPSS) 21.0. The analysis was accomplished from descriptive statistics, using median (Q1Q3) for continuous variables and absolute and relative frequency for the categorical variables. For the bivariate analyses of the categorical variables, the chi-square test was used and, for the continuous tests the Mann-Whitney test was used.

Variables that presented $p<0.2$ in the bivariate analyzes were included in a multivariate logical regression model, with a backward method. The results were then expressed in Odds Ratio (OR) and their respective $95 \%$ confidence intervals with and without adjustment. For all analyzes, the final level of significance was $5 \%(p<0.05)$.

This study complies with Resolution 466/2012 of the National Health Council, and is approved by the Research Ethics Committee of Faculdade Independente do Nordeste (FAINOR), with written opinion No. 2.015.327 and CAAE No.: 66705617.2.0000.5578. All the participants in this study were informed about the study by reading the Free and Informed Consent Term, and the research was accomplished only after their understanding, agreement and signature. 


\section{Results}

Among the evaluated hypertensive individuals, the prevalence of adherence to drug treatment was $62.9 \%$. Age ranged from 26 to 79 years old, with a median of 60 years old (Q1-Q3: 52.0-69.0). When evaluated between the groups (that is, adherent or non-adherent), the median age of the adherent group was 62 years old (55.0-71.0), while the non-adherent age was 55.5 years old (48.0-66.0), with differences between groups being statistically significant ( $p$ $<0.001)$.

$91 \%$ of the people who adhere to the treatment live with a partner or with other relatives (consanguineous or not).

Regarding the socio-demographic variables, there was predominance among the female gender (67\%). Regarding the educational level, it was verified that the participants with less than one year of schooling adhered more to antihypertensive drugs (70.6\%). Regarding race/skin color, $63.4 \%$ of black hypertensive individuals (including mulattos) adhere to the medication. As for the marital and family situation, $91 \%$ of the people who adhere to the treatment live with a partner or with other relatives (consanguineous or not). It is observed that there was greater adherence in people receiving income less than or equal to one minimum wage $(62.7 \%)$, retired (66.7\%) and not working (65.4\%). This characterization is found in Table 1.

Table 1. Socio-demographic characteristics of hypertensive Afrodescendants resident in Quilombola community in relation to drug adherence. Jequié, BA, Brazil, 2018.

\begin{tabular}{|c|c|c|c|}
\hline \multirow[t]{2}{*}{ Characteristics } & \multicolumn{2}{|c|}{ Drug Adherence* } & \multirow[b]{2}{*}{$\mathbf{P}$} \\
\hline & $\begin{array}{c}\text { No } \\
\text { n (\%) } \\
\end{array}$ & $\begin{array}{c}\text { Yes } \\
\text { n (\%) } \\
\end{array}$ & \\
\hline Gender $(n=302)$ & & & $0.002^{*}$ \\
\hline Male & $41(47.1)$ & $46(52.9)$ & \\
\hline Female & $71(33.0)$ & $144(67.0)$ & \\
\hline Schooling $(n=302)$ & & & 0.062 \\
\hline$<1$ year of schooling & $37(29.4)$ & $89(70.6)$ & \\
\hline From 1 to 8 years of schooling & $61(42.4)$ & $83(57.6)$ & \\
\hline$>8$ years of study & $14(43.8)$ & $18(56.3)$ & \\
\hline Race/color $(n=302)$ & & & 0.615 \\
\hline Black people & $100(36.6)$ & $173(63.4)$ & \\
\hline Not black people & $12(41.4)$ & $17(58.6)$ & \\
\hline Marital/family status $(n=302)$ & & & 0.180 \\
\hline Has a partner & $74(41.3)$ & $105(58.7)$ & \\
\hline With other relatives & $30(31.3)$ & $66(68.8)$ & \\
\hline Live alone & $8(29.6)$ & $19(70.4)$ & \\
\hline Income $(n=278)$ & & & 0.927 \\
\hline$<$ one wage & $82(37.3)$ & $138(62.7)$ & \\
\hline > one wage & $22(37.9)$ & $36(62.1)$ & \\
\hline \multicolumn{4}{|l|}{ Occupation $(n=302)$} \\
\hline Works & $76(38.4)$ & $122(61.6)$ & 0.934 \\
\hline Does not work & $28(34.6)$ & $53(65.4)$ & \\
\hline Retired & $3(33.3)$ & $6(66.7)$ & \\
\hline Others & $5(35.7)$ & 9 (64.3) & \\
\hline
\end{tabular}

SOURCE: research data. *divergences between the totals of each category are due to non-responses

Regarding the health aspects, the median of systolic blood pressure (SBP) was $147 \mathrm{mmHg}$, while diastolic blood pressure (DBP) $85 \mathrm{mmHg}$. When comparing systolic SBP and DBP between the 
groups (adherent and non-adherent), both SBP and DBP in the non-adherent group were higher, as shown in figure 1.
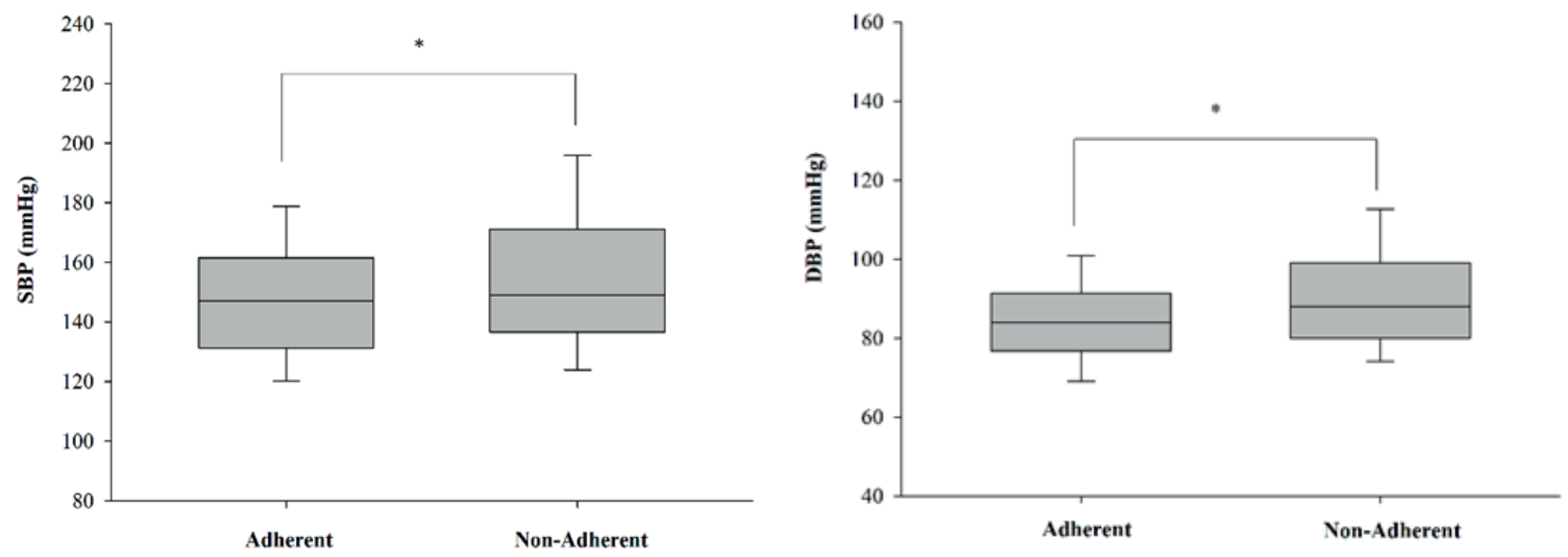

Figure 1. Median and interquartile range of systolic (SBP) and diastolic (DBP) blood pressure between adherent and non-adherent individuals. Jequié, 2018.

SOURCE: research data. *Statistically significant difference to SPB $(p=0,007)$ and DPB $(p=0,002)$.

Hypertensive drug users who reported type 2 diabetes $(67.1 \%)$ and had a family history of cardiovascular disease (CVD), who did not smoke (63.7\%) and did not practice physical activity (64, 7\%) (Table 2).

Table 2. Health aspects for hypertensive Afrodescendants resident in Quilombola community in relation to pharmacological adherence. Jequié, BA, Brazil, 2018.*

\begin{tabular}{|c|c|c|}
\hline \multirow[t]{2}{*}{ Characteristics } & \multicolumn{2}{|c|}{$\begin{array}{c}\text { Pharmacological } \\
\text { adherence }\end{array}$} \\
\hline & $\begin{array}{c}\text { No } \\
\text { n (\%) }\end{array}$ & $\begin{array}{l}\text { Yes } \\
\text { n (\%) }\end{array}$ \\
\hline \multicolumn{3}{|c|}{ CVD family history (n=271) } \\
\hline Yes & $55(32.7)$ & $113(67.3)$ \\
\hline No & $42(40.8)$ & $61(59.2)$ \\
\hline \multicolumn{3}{|c|}{ T2 diabetes $(n=220)$} \\
\hline Yes & $23(32.9)$ & $47(67.1)$ \\
\hline No & $57(38.0)$ & $93(62.0)$ \\
\hline \multicolumn{3}{|l|}{ Smoking $(n=302)$} \\
\hline Yes & $13(46.4)$ & $15(53.6)$ \\
\hline No & $99(36.1)$ & $175(63.9)$ \\
\hline \multicolumn{3}{|c|}{ Sedentary life - style $(n=302)$} \\
\hline Yes & $53(34.9)$ & $99(65.1)$ \\
\hline No & $59(39.3)$ & $91(60.7)$ \\
\hline \multicolumn{3}{|c|}{ Categories of BMI $(n=298)$} \\
\hline Not overweight & $24(35.3)$ & $44(64.7)$ \\
\hline With overweight & $87(37.8)$ & $143(62.2)$ \\
\hline
\end{tabular}

SOURCE: research data. $\mathrm{BMI}=$ Body Mass Index; $\mathrm{CVD}=$ Cardiovascular Disease. * divergences between the totals of each category are due to non-responses

The final logistic regression model is shown in Table 3, and it was observed that age was a protective factor for adherence (that is, increased age improved adherence), as well as, the female 
gender. On the other hand, systolic pressure was shown to be a risk factor for adherence (that is, higher systolic pressure values imply worse adherence).

Table 3 - Odds Ratio (OR) with and without adjustment, and confidence interval $95 \%$ of final logistic regression model for pharmacological adherence. Jequie, BA, Brazil, 2018.

\begin{tabular}{lcc}
\hline Characteristics & OR $(\mathbf{9 5 \%} \mathbf{C l})$ & Adjusted OR * $\mathbf{9 5 \%}$ Cl) \\
\hline Age & $0,962(0.963-0.991)$ & $0.954(0.933-0.975)$ \\
SBP & $1,000(0.995-1.023)$ & $1.118(1.003-1.023)$ \\
Female Gender & $0.504(0.290-0.894)$ & $0.497(0.292-0.846)$ \\
\hline
\end{tabular}

SOURCE: research data. Systolic Blood Pressure. *Variables on saturated model were: SPB, DBP, Age, gender and schooling

\section{Discussion}

In the results of this study, being older and being female are factors associated with greater drug adherence, while increases in SBP are linked to poorer adherence, which highlights that biological and behavioral variables are involved in the therapeutic adherence model.

Drug adherence among hypertensive individuals in this study (62.9\%) was lower than the Brazilian mean value $(81.4 \%)^{21}$. When comparing the adherence rate in our study with other national geographic scenarios, it is verified that other cities in the Northeast displayed lower results ${ }^{19,22,}$ with percentages varying from $19.7 \%$ in Maceió-AL to $26.75 \%$ in Teresina-PI. However, research in the Southeast ${ }^{23,24}$ and South regions ${ }^{25}$ have higher adherence rates: $90,7 \%, 70,7 \%$ and 65,7\%. Probable explanations for the divergent percentages refer to using different drug adherence scales $^{26}$.

In other African black populations, such as those living in Ghana, Nigeria ${ }^{27}$ and Nedjo ${ }^{28}$, there are lower adherence rates than those in our study, 33.3\% and $31.4 \%$, being related to the use of medicinal herbs (cultural factor), low knowledge about $\mathrm{AH}$ and access to drug treatment. Probably, the most frequent contact of hypertensive quilombola people in study with the urban community and the health service has reduced this cultural belief and increased the confidence and the attitudes in the drug treatment.

The majority in the studied population belongs to the female gender, as well as data from other studies developed in Brazil $^{29,30}$ and abroad ${ }^{27}$, which demonstrates a greater demand in this group for health services, thus facilitating $\mathrm{AH}$ diagnosis and treatment ${ }^{31}$. In Brazil, this data may be related to the culture of larger female participation in the developed health actions, especially in the FHS.

Unlike previous searches $24,29,32$, in this study the female gender displayed statistical association and it was shown as a protection factor, which contradicts the hypothesis of drug adherence not being influenced by the gender ${ }^{33}$.

Regarding age, other studies are in agreement with the results found in this study, showing that drug adherence is associated with increased age, being more frequent in the elderly (age greater than or equal to 60 years old) ${ }^{18,27,34}$ in relation to people aged between 20 and 59 years old ${ }^{35}$.

The concern with comorbidities or complications experienced by $\mathrm{AH}^{36}$ and the presence of a caregiver may favor the adherence in the elderly. In adults and young people, asymptomatol- 
ogy or little health concern may come to impair this adherence $^{27}$. Therefore, health education actions for the younger age group are imperious.

Other authors ${ }^{14,17}$ have already documented low schooling in quilombola hypertensive individuals, but did not associate it with drug adherence. In this study, although the results were not statistically significant, the hypertensive individuals who adhered to the treatment had lower educational level. This is an inverse relation to the other searches ${ }^{23,18}$, who have identified the low schooling reflected in the lower drug adherence, since it is a limiting factor in understanding the disease and the prescribed treatment ${ }^{30}$. The categorization of schooling adopted in this research (in schooling years) differs from the cited investigations regarding the cut-off point and other heterogeneous categorizations, thus requiring caution in the interpretations.

Regarding financial situation, the literature shows that higher income is associated with better pharmacological adherence 24,35 , which reflects in reducing pressure-related levels. However, a systematic review has pointed out that isolated income analysis may not be the deciding factor for drug adherence ${ }^{37}$.

Although the hypertensive individuals in this study have low income, a similar situation to other black quilombola populations ${ }^{14}$ or not $^{27}$, it is likely that other factors such as free drug accessibility and treatment sensitization may have overlapped the income's variable influence, thus increasing pharmacological adherence in this population.

The World Health Organization defines hypertensive people as those with a systolic blood pressure (SBP) equal to or greater than $140 \mathrm{mmHg}$ and/or diastolic blood pressure (DBP) equal to or greater than $90 \mathrm{mmHg} .{ }^{1}$ In this study there was a greater reduction in SBP and DBP in the group with greater drug adherence, culminating in controlling pressure levels, similar to other studies $25,26,27,33,34$.

A national study on the politics in the black population in the state of Maranhão distinguishes that the main challenges faced in AH control correspond to the lack of training for the professionals, use of inadequate therapeutic protocols and irregular drug distribution by the Unified Health System ${ }^{38}$.

On the other hand, an international survey showed that the increase in $\mathrm{AH}$ control was related to addressing these challenges, in addition to applying other measures such as case management in high-risk patients, regular annual consultation, health education, graduated professionals that perform an active search for non-adherent patients by encouraging them to make appointments at the doctor ${ }^{39}$.

The measures cited in this study are foreseen in the planning and execution of the national health services in the basic units, except for the active search that is not accomplished by a qualified health professional. The orientation of these professionals, especially nurses, has been associated with greater drug adherence ${ }^{40,41}$, whereas guidance from community health agents may increase the odds for non-adherence to antihypertensive medication by up to 2.21 times $^{24}$.

Regarding the race/skin color variable, this study's outcomes identify that - although most of the hypertensive individuals are black and mulattos, which may be associated with the studied 
population group (quilombola people) - there was no significant association with the pharmacological adherence for this variable. An opposing result for this relationship was found in a national study conducted in Paraná-Santa Catarina ${ }^{42}$, when identifying that the majority of hypertensive individuals, who were white (70\%), displayed statistically significant results for a greater adherence.

The isolated association for the race/skin color variable on drug adherence has been little cited in studies in Brazil ${ }^{33,43}$ and abroad ${ }^{44}$. Thus, a deepening in the studies about the relation of the race/skin color variable with drug adherence needs to be developed in order to set up a consensus among the researchers.

Regarding marital and family situation, the results of this research converge with other studies, showing that the motivation offered by cohabiting with a partner ${ }^{26}$ or other relatives ${ }^{33}$ favors drug adherence, and that there may be a significant positive association between these two variables (living with a partner and drug adherence) ${ }^{23}$. In this way, the family can act as an agent facilitating drug adherence by encouraging self-care practices ${ }^{45}$.

The relationship of drug adherence to previous diseases such as type 2 diabetes ${ }^{34}$ and family history of cardiovascular disease ${ }^{29}$, has also been documented in other researches. Probably, the presence of other comorbidities, in addition to hypertension, induces health professionals to devote greater attention to this population, which may result in better rates of pharmacological adherence.

The group of retired and non-working hypertensive individuals displayed greater drug adherence, as already observed in other studies ${ }^{26,43}$. Free time to participate in educational activities and consultations may have influenced this adherence. Among workers, low adherence may be related to compliance with labor standards, influencing them to give up health care, such as forgetting to take medications or delaying their administration ${ }^{46}$ and the inflexibility regarding operational hours for the basic health units ${ }^{47}$. Therefore, it is essential to adapt schedules, both in the functioning of health services, and in drug prescription.

The variables related to lifestyle were smoking and sedentarism. Among the adherents, those hypertensive people who do not smoke or are ex-smokers prevail, similarly to other studies $29,43,46$. The actions of health education, personal aspects or complications in the clinical setting may have influenced the abandonment or non-initiation of the addiction.

Regarding sedentarsim, our results converge with other studies when identifying that hypertensive individuals with sedentary behavior adhere more to the pharmacological treatment ${ }^{34,43}$, which may be related to the challenge in changing life habits ${ }^{48}$ and the difficulty for beginning regular physical activity practices. This data reinforces the importance of health interventions and actions to stimulate the adoption of a healthy lifestyle ${ }^{6}$. The combination of physical exercise and pharmacological treatment can improve blood pressure levels $s^{49,50}$ and quality of life for hypertensive people.

In this study, greater pharmacological adherence was observed among eutrophic hypertensive individuals, culminating with a better blood pressure level ${ }^{34}$. An opposing result was found in the Northeast region by showing that people with $\mathrm{AH}$ who adhered to the drug therapy were dystrophic ${ }^{51}$. The divergence of this result can be related to household activities and manual work practiced by quilombola women and men, causing caloric and BMI reduction. 
This research has limitations related to the absence of a control group and to the selection bias, since most information was self-reported, which does not allow us to make generalizations regarding adherence to the treatment of quilombola hypertensive individuals registered in other services or geographic areas.

The adherence to treatment of chronic conditions is a major challenge for public health and health workers, especially nurses. In this way, this study's results show that health professionals need to design educational actions and interventions that help people living in the urban quilombola community to improve their adherence to drug therapy, aligning it with non-drug therapy, such as adopting healthy life habits that, therefore, promote greater control for blood pressure levels.

\section{Conclusions}

This study verified that adherence to drug treatment was lower when compared to the national average, although it was superior to other cities in the Northeast region of Brazil.

The profile og the users that adhered to hypertension treatment was characterized as being female, median age of 60 years old, having less than one year of schooling, living with someone (partner or other relatives), having a family income less than or equal to a one minimum wage, having type 2 diabetes and a CVD family history, not smoking, being sedentary, not overweight and having a controlled SBP. Of these variables, those with a statistically significant effect as protection factor were females and the increase of age and as, a risk factor, the increased levels of SBP in the non-adherent group.

The data demonstrated in this study is positive regarding drug adherence of black people to hypertension in the Northeast, which shows a modest increase in the participation of this population in public health programs. However, more investment is required in $\mathrm{AH}$ public control policies so that the adherence of this population may match the national average.

The results also reinforce the importance of incorporating motivational and diversified strategies focused on stimulating self-care to unify non-pharmacological treatment, such as physical activity practices, to pharmacological therapy. In addition, health promotion and prevention actions should consider the family core, social and cultural aspects, and encourage the empowerment of these people as active subjects for the change in their own reality.

Conflict of interest: The authors declare that they have no conflict of interest.

Source of funding: None

\section{References}

1. World Health Organization. A global brief on hypertension: silente killer, global public helth crisis. Genebra:WHO; 2013.

2. GBD 2013 Risk Factors Collaborators, Forouzanfar MH, Alexander L, Anderson HR, Bachman VF, Biryukov S, et al. Global, regional, and national comparative risk assessment of 79 behavioural, environmental and occupational, and metabolic risk factors or clusters of risks in 188 countries, 1990-2013: a systematic analysis for the Global Burden of Disease Study 2013. Lancet. 2015;386(10010):2287-323. https://doi.org/10.1016/S0140-6736(15)00128-2 
3. Araújo ASS, Rizzato SS, Scalioni BA, Sampaio CP, Landmann SC, Carvalho MD. Prevalência de hipertensão arterial autorreferida na população brasileira: análise da Pesquisa Nacional de Saúde, 2013. Epidemiol Serv Saúde. 2015;24:297-304.

https://doi.org/10.5123/S1679-49742015000200012

4. Hyman DJ, Pavlik V. Medication adherence and resistant and hypertension. J Hum Hypertens. 2015;29 (4):213-8. https://doi.org/10.1038/jhh.2014.73

5. WORLD HEALTH ORGANIZATION (WHO). Adherence to long-term therapies: evidence for action. Genebra: WHO, 2003.

6. Raymundo ACN, Pierin AMG. Adesão ao tratamento de hipertensos em um programa de gestão de doenças crônicas: estudo longitudinal retrospectivo. Rev Esc Enferm USP. 2014;48(5):811-9.

7. Freitas JGA, Nielson SEO, Porto CC. Adesão ao tratamento farmacológico em idosos hipertensos: uma revisão integrativa da literatura. Rev Soc Bras Clin Med. 2015;13(1):75-84.

8. Marin NS, Santos MF, Moro AS. Percepção de hipertensos sobre a sua não adesão ao uso de medicamentos. Rev Esc Enferm USP. 2016;50:061-067.

9. Thomas SJ, Booth JN 3rd, Dai C, Li X, Allen N, Calhoun D, Carson AP, Gidding S, Lewis CE, Shikany JM, Shimbo D, Sidney S, Muntner P. Cumulative incidence of hypertension by 55 years of age in blacks and whites: The CARDIA Study. J Am Heart Assoc. 2018;7(14):e007988. https://doi.org/10.1161/JAHA.117.007988

10.Yoon SS, Fryar CD, \& Carroll MD. Hypertension prevalence and control among adults: United States, 2011-2014. NCHS Data Brief. 2015;(220):1-8.

11.Brazil. Lei no 12.288, de 20 julho de 2010. Institui sobre a Igualdade Racial. Presidência da República Casa Civil Subchefia para Assuntos Jurídicos, 20 julho de 2010.

12.Bezerra VM, Andrade ACS, César CC, Caiaffa WT. Comunidades quilombolas de Vitória da Conquista, Bahia, Brasil: hipertensão arterial e fatores associados. Cad Saúde Pública. 2013;29(9):1889-902. https://doi.org/10.1590/S0102-311X2013001300027

13.Brazil. Decreto no 4.887, de 20 de novembro de 2003. Regulamenta o procedimento para identificação, reconhecimento, delimitação, demarcação e titulação das terras ocupadas por remanescentes das comunidades dos quilombos de que trata o art. 68 do Ato das Disposições Constitucionais Transitórias. Diário Oficial da União, Brasília, 21 de novembro de 2003. Disponível em: http://www.planalto.gov.br/ccivil_03/decreto/2003/D4887.htm

14.Bezerra VM, Medeiros DS, Gomes KO, Souzas R, Giatti L, Steffens AP, et al. Inquérito de Saúde em Comunidades Quilombolas de Vitória da Conquista, Bahia, Brasil (Projeto COMQUISTA): aspectos metodológicos e análise descritiva. Ciênc Saúde Coletiva. 2014;19(6):183547. https://doi.org/10.1590/1413-81232014196.01992013

15.Pinho L, Dias RL, Cruz LMA, Velloso NA. Condições de saúde de comunidade quilombola no norte de Minas Gerais. Rev Pesqui Cuid Fundam Online. 2015;7(1):1847-55.

https://doi.org/10.9789/2175-5361.2015.v7i1.1847-1855

16.Santos VC, Boery EN, Boery RNSO, Anjos KF. Conditions of health and quality of life of the quilombola elderly black. J Nurs UFPE Online. 2014;8(8):321-7.

17.Santos VC, Boery EM, Pereira R, Rosa DOS, Vilela ABA, Anjos KFK, et al. Condições socioeconômicas e de saúde associadas á qualidade de vida de idosos quilombolas. Texto \& Contexto Enferm. 2016;25(2):e1300015. https://doi.org/10.1590/0104-07072016001300015

18.Tavares NUL, Bertoldi AD, Mengue SS, Arrais PSD, Luiza VL, Oliveira MA, et al. Fatores associados à baixa adesão ao tratamento farmacológico de doenças crônicas no Brasil. Rev Saúde Pública. 2016;50(supl 2):10s.

19. Oliveira-Filho AD, Barreto-Filho JA, Neves SJF, Lyra Junior DP. Relação entre a Escala de Adesão Terapêutica de oito itens de Morisky (MMAS-8) e o controle da pressão arterial. Arq Bras Cardiol. 2012;99(1):649-58. https://doi.org/10.1590/S0066-782X2012005000053

20.Oliveira-Filho AD, Morisky DE, Neves SJ, Costa FA, Lyra DP Jr. The 8-item Morisky Medication. Adherence Scale: validation of a Brazilian-Portuguese version in hypertensive adults. 
Res Social Adm Pharm. 2014;10(3):554-61. https://doi.org/10.1016/j.sapharm.2013.10.006

21.Malta DC, Stopa SR, Andrade SSCA, Szwarcwald CL, Silva Júnior JB, Reis AAC. Cuidado em saúde em adultos com hipertensão arterial autorreferida no Brasil segundo dados da Pesquisa Nacional de Saúde, 2013. Rev Bras Epidemiol. 2015;18(suppl 2):109-22.

https://doi.org/10.1590/1980-5497201500060010

22. Carvalho ALM, Leopoldino RWD, Silva JEG, Cunha CP. Adesão ao tratamento medicamentoso em usuários cadastrados no Programa Hiperdia no município de Teresina (PI). Ciênc Saúde Coletiva. 2012;17(7):1885-92. https://doi.org/10.1590/S1413-81232012000700028

23.Ferreira MA, Iwamoto HH. Determinantes da adesão ao tratamento de usuários com hipertensão cadastrados no programa hiperdia da atenção primária à saúde. REME - Rev Min Enferm. 2017;21:e-1037.

24.Gomes e Martins A, Chavaglia SRR, OhI RIB, Martins IML, Gamba MA. Adesão ao tratamento clínico ambulatorial da hipertensão arterial sistêmica. Acta Paul Enferm. 2014;27(3):266-72. https://doi.org/10.1590/1982-0194201400045

25.Grezzana GB, Stein AT, Pellanda LC. Adesão ao tratamento e controle da pressão arterial por meio da monitoração ambulatorial de 24 horas. Arq Bras Cardiol. 2013;100(4):355-61.

26.Silva LFRS, Marino JMR, Guidoni CM, Girotto E. Fatores associados à adesão ao tratamento anti-hipertensivo por idosos na atenção primária. Rev Ciênc Farm Básica Apl. 2014;35(2):27178.

27. Boima V, Ademola AD, Odusola AO, Agyekum F, Nwafor CE, Cole $\mathrm{H}$, et al. Factors Associated with Medication Nonadherence among Hypertensives in Ghana and Nigeria. Int J Hypertens. 2015;2015:205716. https://doi.org/10.1155/2015/205716

28.Berisa HD, Dedefo MG. Non-Adherence Related Factors to Antihypertensive Medications Among Hypertensive Patients on Follow up at Nedjo General Hospital in West Ethiopia. Open Pub Health J. 2018;11:62-71. https://doi.org/10.2174/1874944501811010062

29.Mansour SN, Monteiro CN, Luiz OC. Adesão ao tratamento farmacológico de pacientes hipertensos entre participantes do Programa Remédio em Casa. Epidemiol Serv Saúde. 2016;25(3):647-54. https://doi.org/10.5123/S1679-49742016000300021

30.Martins AG, Chavaglia SR, OhI RI, Martins IM, Gamba MA. Compliance with outpatient clinical treatment of hypertension. Acta Paul Enferm. 2014;27(3):266-72.

https://doi.org/10.1590/1982-0194201400045

31.Mengue SS, Bertoldi AD, Ramos LR, Farias MR, Oliveira MA, Tavares NUL, et al. Acesso e uso de medicamentos para hipertensão arterial no Brasil. Rev Saúde Pública. 2016;50(supl 2):8s.

32. Osamor PE. Social support and management of hypertension in southwest Nigeria. Cardiovasc J Afr. 2015;26:29-33. https://doi.org/10.5830/CVJA-2014-066

33.Bezerra ASM, Lopes JL, Barros ALBL. Adesão de pacientes hipertensos ao tratamento medicamentoso. Rev Bras Enferm. 2014 jul-ago;67(4):550-5.

https://doi.org/10.1590/0034-7167.2014670408

34.Khayyat SM, Khayyat SMS, Alhazmi RSH, Mohamed MMA, Hadi MA. Predictors of Medication Adherence and Blood Pressure Control among Saudi Hypertensive Patients Attending Primary Care Clinics: A Cross-Sectional Study. PLoS One. 2017;12(10):e0187614. https://doi.org/10.1371/journal.pone.0187614

35.Magnabosco P, Teraoka EC, Oliveira EM, Felipe EA, Freitas D, Marchi-Alves LM. Análise comparativa da não adesão ao tratamento medicamentoso da hipertensão arterial sistêmica em população urbana e rural. Rev Latino-Am Enfermagem. 2015;23(1):20-7.

https://doi.org/10.1590/0104-1169.0144.2520

36.Nguyen T-P-L, Schuiling-Veninga CCM, Nguyen TBY, Vu T-H, Wright EP, Postma MJ. Adherence to hypertension medication: Quantitative and qualitative investigations in a rural Northern Vietnamese community. PLoS One. 2017;12(2):e0171203. 
https://doi.org/10.1371/journal.pone.0171203

37.Mathes T, Jaschinski T, Pieper D. Adherence influencing factors - a systematic review of systematic reviews. Arch Public Health. 2014;72:37. https://doi.org/10.1186/2049-3258-72-37

38.Varga IVD, Cardoso RLS. Controle da hipertensão arterial sistêmica na população negra no Maranhão: problemas e desafios. Saúde Soc. 2016;25(3): 664-71. https://doi.org/10.1590/s0104-129020162616

39.Jaffe MG, Lee GA, Young JD, Sidney S, Go AS. Improved blood pressure control associated with a large-scale hypertension program. JAMA. 2013;310(7):699-705.

https://doi.org/10.1001/jama.2013.108769

40.Costa YF, Araújo OC, Almeida LBM, Viegas SMF. O papel educativo do enfermeiro na adesão ao tratamento da Hipertensão Arterial Sistêmica: revisão integrativa da literatura. Mundo Saúde. 2014;38(4):473-81. https://doi.org/10.15343/0104-7809.20143804473481

41.Dias EG, Souza ELS, Mishima SM. Contribuições da enfermagem na adesão ao tratamento da hipertensão arterial: uma revisão integrativa da literatura brasileira. Rev Epidemiol Control Infec. 2016;6(3):138-44. https://doi.org/10.17058/reci.v6i3.7470

42.Barreto MS, Cremonese IZ, Janeiro V, Matsuda LM, Marcon SS. Prevalência de não adesão à farmacoterapia anti-hipertensiva e fatores associados. Rev Bras Enferm. 2015;68(1):60-7. https://doi.org/10.1590/0034-7167.2015680109p

43. Moura AA, Godoy SC, Bernardi C, Mendes IAC. Fatores da não adesão ao tratamento da hipertensão arterial. Enferm Glob. 2016;15(43):14-27.

https://doi.org/10.6018/eglobal.15.3.219601

44.Wong ES, Maciejewski ML, Liu CF. Does the association between prescription copayment increases and medication adherence differ by race? J Health Care Poor Underserved. 2013;24(3):1317-30. https://doi.org/10.1353/hpu.2013.0152

45.Barreto MS, Marcon SS. Participação familiar no tratamento da hipertensão arterial na perspectiva do doente. Texto \& Contexto Enferm. 2014;23(1):38-46. https://doi.org/10.1590/S0104-07072014000100005

46.Ezeala-Adikaibe BA, Mbadiwe N, Okudo G, Nwosu N, Nwobodo N. Factors associated with medication adherence among hypertensive patients in a tertiary health center: $\mathrm{A}$ Cross-Sectional Study. Arch Community Med Public Health. 2017;3(1):024-031. https://doi.org/10.17352/2455-5479.000021

47.Fontana KC, Lacerda JT, Machado PMO. O processo de trabalho na Atenção Básica à saúde: avaliação da gestão. Saúde Debate. 2016;40(110):64-80. https://doi.org/10.1590/0103-1104201611005

48.Kleinsinger $\mathbf{F}$. The Unmet Challenge of Medication Nonadherence. Perm J Perm J. 2018;22:18033. https://doi.org/10.7812/TPP/18-033

49.Bolin LP, Crane PB, Powell JR, Horne CE, Floegel TA. Factors associated with physical activity in African Americans with hypertension. Appl Nurs Res. 2018;4:62-7. https://doi.org/10.1016/j.apnr.2018.04.003

50.Malachias MVB, Souza WKSB, Plavnik FL, Rodrigues CIS, Brandão AA, Neves MFT, et al. Sociedade Brasileira de Cardiologia; Sociedade Brasileira de Hipertensão; Sociedade Brasileira de Nefrologia. 7 th Brazilian Guideline of Arterial Hypertension. Arq Bras Cardiol 2016; 107 (Suppl 3):1-83.

51.Ribeiro IJS, Boery RNSO, Casotti CA, Freire IV, Teixeira JRB, Boery EN. Prevalência e fatores associados à adesão ao tratamento medicamentoso por pacientes com hipertensão arterial. Rev Baiana Enferm. 2015; 29(3): 250-60. https://doi.org/10.18471/rbe.v29i3.12920 